\title{
VIETNAM \\ AN ANALYSIS ON THE STATUS OF DEMOCRACY AND POLITICAL DEVELOPMENT IN A ONE-PARTY STATE
}

\author{
Lucas Rivers \\ Master of Public Administration, Economic \& Political Development \\ Columbia University, School of International and Public Affairs
}

November 1, 2018 


\section{INTRODUCTION}

Vietnam is one of the fastest growing economies in the world. ${ }^{1}$ Over the past 30 years, Vietnam has transformed itself from one of the world's poorest nations to a lower-middle income country ripe with investment opportunities. ${ }^{2}$ Yet despite these economic achievements, this one-party state still encounters significant obstacles to sustained and democratic political development in each of the USAID's five key elements of democracy, human rights and governance: consensus, inclusion, competition and political accountability, rule of law and human rights, and government responsiveness and effectiveness. ${ }^{3}$

\section{VIETNAM IN CONTEXT}

\section{Colonialism, Conflict, \& Communism: An Historical Perspective}

Vietnam's political history is one marked by colonial conquests, military conflicts, and regional tensions that span across many centuries. Much of this historical narrative finds its origins in the one thousand years of Chinese rule over Vietnam until A.D. 938, which left long-lasting influences on Vietnamese culture, education, law, and language. ${ }^{4}$ In the nine centuries of independence that followed, internal struggles and warfare between the Nguyễn and Trịnh noble families eventually lead to a weakened Vietnam vulnerable to the colonial pursuits of the French. ${ }^{5}$ Anxious that their

\footnotetext{
1 "The Fastest-growing and Shrinking Economies in 2018." The Economist. January 05, 2018. Accessed October 28, 2018. https://www.economist.com/graphic-detail/2018/01/05/the-fastest-growing-and-shrinking-economies-in-2018.

${ }^{2}$ Jennings, Ralph. "Vietnam's Economic Growth Will Accelerate In 2018 As Investors Flood The Country." Forbes. December $27,2017$. Accessed October 18, 2018. https://www.forbes.com/sites/ralphjennings/2017/12/27/vietnams-economy-will-soar-again-in-2018because-investors-just-love-it/\#1584d9c355df.

${ }^{3}$ USAID. “Country Development Cooperation Strategy for Vietnam (2014-2019).” November 8, 2013. Accessed October 7, 2018. https://www.usaid.gov/vietnam/cdes

${ }^{4}$ Odell, Andrew L., and Marlene F. Castillo. "Vietnam in a Nutshell: An Historical, Political and Commercial Overview." NYSBA International Law Practicum 21, no. 2 (2008). Accessed October 14, 2018. https://www.duanemorris.com/articles/static/odell inpr aut08.pdf.

5 "Vietnam Review 2018." Country Watch. 2017. Accessed October 28, 2018. http://www.countrywatch.com/Content/pdfs/reviews/B4838389.01c.pdf.
} 
footprint in Asia was falling behind that of their European peers, the French succeeded in bringing Vietnam into their global empire in 1887 as part of French Indochina. ${ }^{6}$

In the early $20^{\text {th }}$ century, French suppression of Vietnamese modernization movements Đông Du ("Go East") and Duy Tân ("Modernization") - led revolutionaries to turn to Marxism with the founding of the Vietnamese Communist Party in $1930 .{ }^{7}$ With the foundations now in place, the Vietnamese Communist Party was able to set the stage for the struggle against foreign rule - including the Japanese following their invasion during World War II - lead by Vietnamese revolutionary Ho Chi Minh's Việt Minh umbrella group. ${ }^{8}$ In 1947, war erupted between the French and the Việt Minh, leading to the Geneva Accords of 1954 that ended France's colonial presence and divided the country into the communist North and anti-communist South. ${ }^{9}$

In the 1960s, South Vietnam became incredibly unstable, leading the U.S. to send troops and economic aid to the South while simultaneously bombarding the North in what would soon become a long and violent war. ${ }^{10}$ In 1975 , North Vietnam overran the South, reuniting the country under communist rule under the Socialist Republic of Vietnam and the leadership of Ho Chi Minh. ${ }^{11}$ This rapid victory left little time for preparation, resulting in a unified country without a post-war plan on how to unite the disparate socialist and capitalist economies. In the decade that followed the victory, economic stagnation gripped the one-party state, particularly as skirmishes between Cambodia and China resulted in large military budgets and growing international isolation. ${ }^{12}$ Yet as other one-party states in the world started to relax state control over their

\footnotetext{
6 "The World Factbook: VIETNAM." Central Intelligence Agency. October 24, 2018. Accessed October 26, 2018. https://www.cia.gov/library/publications/the-world-factbook/geos/vm.html.

${ }^{7}$ Odell, Andrew L., and Marlene F. Castillo. "Vietnam in a Nutshell: An Historical, Political and Commercial Overview." NYSBA International Law Practicum 21, no. 2 (2008). Accessed October 14, 2018. https://www.duanemorris.com/articles/static/odell inpr aut08.pdf.

9 "The World Factbook: VIETNAM." Central Intelligence Agency. October 24, 2018. Accessed October $26,2018$. https:/www.cia.gov/library/publications/the-world-factbook/geos/vm.html.

${ }^{10}$ Ibid.

${ }^{11}$ Lien, Vu Hong, and Peter Sharrock. Descending Dragon, Rising Tiger: A History of Vietnam. London: Reaktion Books, 2014.

12 "The Evolution of U.S.-Vietnam Ties." Council on Foreign Relations. Accessed October 24, 2018. https://www.cfr.org/backgrounder/evolution-us-vietnam-ties.
} 
economies, Vietnamese leaders began exploring ways to ease their economic hardships and continue rebuilding their devastated nation.

\section{Reform, Recovery, \& "Renovation": A Current Perspective}

In December 1986, the $6^{\text {th }}$ National Congress of Vietnam's Communist Party decided to abandon the central planning model of socialism in favor of a "market-oriented socialist economy under state guidance." ${ }^{13}$ Termed Đổi Mới (Renovation), these sweeping economic and political reforms - in concert with a 1992 revision of the Constitution favoring progressive relations with both the world and capitalism - set the stage for a dramatic transformation that would launch the isolated one-party state into a period of rapid growth and development. ${ }^{14}$ From 1991-2000, Vietnam's economy began to grow at an average annual rate of $7.5 \%{ }^{15}$, only catalyzed by the lift of the U.S. trade embargo in 1993 and the full normalization of diplomatic relations in $1995 .{ }^{16}$

Vietnam's current economic performance is propelled by robust bilateral trade relationships with the United States and China $-20.1 \%$ and $14.5 \%$ of Vietnam's total exports, respectively. ${ }^{17}$ Vietnam's current GDP of \$223 billion - 15 times the size of the pre-Đổi Mới years $^{18}$ - is witnessing a slow shift away from the agricultural sector to the industrial, with welldiversified sub-sectors of mining, garments, footwear, and vehicle assembly accounting for 33\% of GDP. ${ }^{19}$ This growth is only undergirded by an immense expansion of the service and retail

\footnotetext{
${ }^{13}$ D Melanie Beresford. "Doi Moi in review: The challenges of building market socialism in Vietnam." Journal of Contemporary Asia. 2008. $38: 2$, pp. $221-243$ 
sectors, each supported by record levels of private consumption and tourism in the last five years. ${ }^{20}$ Investors have also flooded the country, with Vietnam's Ministry of Planning and Investment reporting registered FDI at $\$ 29.68$ billion and a $23 \%$ increase in foreign-operated factories throughout 2017, much of which originated in South Korea, Singapore, Japan, or Taiwan. ${ }^{21}$ The integration into international markets and subsequent high economic growth over the past two decades has translated into greater economic opportunity and decreasing poverty rates across the country, all while creating greater unequal distribution of incomes and widespread corruption.

In recent years, Vietnamese leadership has positioned the purge of high level officials accused of corruption at the center of national politics. At the helm of this crackdown is Nguyễn Phú Trọng, the current General Secretary of the Communist Party of Vietnam and newly appointed President following President Trần Đại Quang's death on September 21, 2018. ${ }^{22}$ In a rare consolidation of power unseen since the days of the Vietnam-American War, Nguyễn Phú Trọng's ascendancy to the two highest positions in the Vietnamese government has only solidified growing international and domestic concerns over what many consider "strongman tendencies." 23 Vietnam's political framework rests on the very notion of consensus, with a "four-pillar" system designed to diffuse power at the top. The president, prime minister, chairperson of the National Assembly, and General Secretary of the Communist Party of Vietnam all have equal footing in Vietnam's top leadership. That being said, recent events now leave Trọng with half of the power in a structure meant to originally act as a check and balance on top leaders. ${ }^{24}$

\footnotetext{
20 "Country Overview: Vietnam" World Bank. Accessed October 26, 2018. https://www.worldbank.org/en/country/vietnam/overview.

${ }^{21}$ Jennings, Ralph. "Vietnam's Economic Growth Will Accelerate In 2018 As Investors Flood The Country." Forbes. December $27,2017$. Accessed October 31, 2018. https://www.forbes.com/sites/ralphjennings/2017/12/27/vietnams-economy-will-soar-again-in-2018because-investors-just-love-it/\#1584d9c355df.

${ }^{22}$ Ives, Mike. "Tran Dai Quang, Hard-Line Vietnamese President, Dies at 61." The New York Times. September 21, 2018. Accessed October 27, 2018. https://www.nytimes.com/2018/09/21/obituaries/tran-dai-quang-dead.html.

${ }^{23}$ Campbell, Charlie. "Vietnam: Nguyen Phu Trong Becomes New Strongman President." Time. October 24, 2018. Accessed October $31,2018$.

${ }^{24}$ Ibid. http://time.com/5432855/nguyen-phu-trong-vietnam-president/.
} 


\section{USAID ANALYTICAL FRAMEWORK}

\section{Consensus}

As a one-party state, Vietnamese political life and culture are dominated by the ideology and tenets of the Communist Party, leaving little room for disagreement or diverse perspectives. While "artificial" consensus may exist within the country, this is due in no small part to the use of intimidation and coercion to force a public dialogue that aligns with the interests of the party. While there are limited opportunities for civic engagement, this should not be mistaken for an ability to openly engage in the public sphere, check the government's power, or influence government policy. ${ }^{25}$ Additionally, social and cultural norms play an important role in society, particularly in creating the artificial consensus touted by the regime. Nevertheless, these norms are responsible for the exclusion of ethnic minorities, women, and other marginalized communities in much of the public sphere. ${ }^{26}$

\section{Political \& Ideological Pluralism}

The government continues to actively suppress and restrict any public debate or criticism of the one-party state, effectively abolishing any semblance of national dialogue or consultative processes. Opposition parties to the CPV are illegal and any members affiliating with such are subject to arrest and imprisonment. ${ }^{27}$ The constitution asserts that the CPV is the "vanguard of the working class and the Vietnamese nation... [and] the leading force in the state and society." 28 As such, Vietnamese political life is often described as "mono-organizational socialism", with one

\footnotetext{
${ }^{25}$ OECD. “Social Cohesion Policy Review of Viet Nam.” Development Centre Studies, OECD Publishing, October 28, 2014. Accessed October 27, 2018. Paris, https://doi.org/10.1787/9789264196155-en. 
party exercising full control over state institutions, military forces, and organizations in society. ${ }^{29}$ This forced consensus actively prevents the development and proliferation of alternative narratives, ideologies, or opinions related to political culture and life. This is witnessed in the state's crackdown and suppression of political expression through surveillance, intimidation, and confiscations of computers and cell phones in recent years. ${ }^{30}$ Similarly, university professors and student groups have been instructed by the government to refrain from teaching or writing on political topics that may undermine the state, with reports of university students engaged in human rights advocacy being prevented from graduating. ${ }^{31}$ Although ethnic minorities and women are represented within the $\mathrm{CPV}$, their numbers are few due to the societal biases that discourage these individuals from "running for office." ${ }^{32}$ Rare moments in recent years have offered some resemblance to pluralism in the state, most notably a 2013 initiative by the party that welcomed critique and public comment on the national constitution. ${ }^{33}$

\section{Acknowledgement of Human Rights Abuses}

Vietnam's human rights situation has been the subject of international scrutiny for many decades, though the government has done little to acknowledge these abuses. As a one-party state, violations of international human rights norms are commonplace, with civil liberties being virtually nonexistent, human rights activists consistently assaulted or detained, and no recognition for civil society groups engaged in human rights- and governance-related work. ${ }^{34}$ A 2017 Human Rights

\footnotetext{
${ }^{29}$ Thayer, Carlyle A. "Vietnam and the Challenge of Political Civil Society." April 2009. Vol. 31, No. 1 pp 1-27.

30 "Vietnam 2016 Human Rights Report." U.S. Department of State, Bureau for Democracy, Human Rights and Labor. 2016. Accessed October 28, 2018. https://www.state.gov/j/drl/rls/hrrpt/2016humanrightsreport/index.htm?year=2016\&dlid=265386\#wrapper”.

31 "Vietnam." Freedom House. May 04, 2018. Accessed October 22, 2018. https://freedomhouse.org/report/freedom-world/2018/vietnam

${ }^{32}$ Ibid.

33 "In Surprise Move, Vietnam Asks Citizens for Public Comment on Their Constitution." The Christian Science Monitor. March 26, 2013. Accessed October 29, 2018. https://www.csmonitor.com/World/Asia-Pacific/2013/0326/In-surprise-move-Vietnam-asks-citizens-forpublic-comment-on-their-constitution.

34 "Vietnam." Freedom House. May 04, 2018. Accessed October 22, 2018. https://freedomhouse.org/report/freedom-world/2018/vietnam
} 
Watch report highlighted 36 incidents of men in civilian clothes beating activists over a span of four months, ${ }^{35}$ while a September 2017 report detailed police using excessive force to disperse protestors of a Hong Kong-owned textile factory in Hải Dương - a textbook example of Vietnamese police cracking down on public gatherings, assemblies, or protests. ${ }^{36}$ Furthermore, intimidation and harassment have been cited by police and local officials against religious groups operating outside government-controlled institutions. The Cao Đài church, Hòa Hảo Buddhist sect, independent Protestant and Catholic churches, and the Unified Buddhist Church are all examples of religious institutions under constant surveillance by state authorities. ${ }^{37}$

Forced labor in construction, fishing, agriculture, and manufacturing is common for employed Vietnamese men, as well as used as a punitive measure by the Vietnamese government for a number of crimes. Women and children are subjected to sex trafficking in China, Cambodia, Laos, and Thailand, as well as brokered marriages, domestic servitude, and forced prostitution at home and abroad. ${ }^{38}$ While the Vietnamese government has made strides in the last five years to identify victims and provide guidance to local authorities on implementing anti-trafficking plans, a lack of coordination between agencies and inadequate funding have stymied results. ${ }^{39}$

\section{Inclusion}

Vietnam continues to experience impressive economic growth, yet many vulnerable populations throughout the country have neither witnessed nor reaped the benefits. Though not an exhaustive list, ethnic minorities, persons with disabilities, rural households, those living with HIV/AIDS, and

\footnotetext{
${ }^{35}$ Human Rights Watch. “The Crackdown on Labor Rights Activists.” May 4, 2009. Accessed October 30, 2018.

${ }_{36} \mathrm{https://www.hrw.org/report/2009/05/04/not-yet-workers-paradise/vietnams-suppression-independent-workers-movement}$

${ }^{36}$ Ibid.

38 “Trafficking in Persons Report: 2018." US Department of State. 2018. Accessed October 30, 2018. https://www.state.gov/j/tip/rls/tiprpt/2018/index.htm

39 "Vietnam." Freedom House. May 04, 2018. Accessed October 22, 2018. https://freedomhouse.org/report/freedom-world/2018/vietnam
} 
women all continue to struggle to gain access to adequate social services and equal economic opportunities. ${ }^{40}$ While the past decade has brought national laws and constitutional provisions aimed at preventing discrimination and providing equal access to public services, substantial societal and economic obstacles - as well as systemic corruption and disregard on behalf of public officials - have rendered many of these initiatives futile.

\section{Ethnic Minorities}

Vietnamese law prohibits discrimination against ethnic minorities, though societal discrimination and disparity still exist between the country's 53 ethnic minority groups and the majority Kinh people. ${ }^{41}$ Despite making up around $13 \%$ of Vietnam's total population, ethnic minority groups account for $66 \%$ of people living in extreme poverty and possess significantly higher child and maternal mortality rates. ${ }^{42}$ In the rural Northern and Central Highland regions, where a majority of ethnic minorities live, public officials have been cited preventing children from accessing education and forcing local families to perform or modify cultural practices to satisfy tourist demand. ${ }^{43}$ In a 2016 report to the UN Committee on Economic, Social, and Cultural Rights, the Vietnamese government stated that they would "preserve selectively and phase out the obsolete [traditions]" when referencing certain ethnic minority groups. ${ }^{44}$ And while Article 5 of the Law on Belief and Religion adopted by the National Assembly in 2016 forbids discrimination against beliefs and religion, the stigmatization of religious people - most of whom are ethnic minorities -

\footnotetext{
${ }^{40}$ USAID. “Country Development Cooperation Strategy for Vietnam (2014-2019).” November 8, 2013. Accessed October 7, 2018. https://www.usaid.gov/vietnam/cdes

${ }^{41}$ Bob Baulch, Truong Thi Kim Chuyen, Dominique Haughton \& Jonathan Haughton. "Ethnic minority development in Vietnam.” 2007. The Journal of Development Studies, 43:7, 1151-1176.

42 "Out of Sight." The Economist. April 04, 2015. Accessed October 27, 2018. https://www.economist.com/asia/2015/04/04/out-of-sight.

${ }^{43}$ Vietnam 2016 Human Rights Report." U.S. Department of State, Bureau for Democracy, Human Rights and Labor. 2016. Accessed October

${ }^{44}$ Ibid. 28, 2018. https://www.state.gov/j/drl/rls/hrrpt/2016humanrightsreport/index.htm?year=2016\&dlid=265386\#wrapper”.
} 
has remained unchanged. ${ }^{45}$ Nonetheless, ethnic minorities in Vietnam have seen an increase in decision-making power and representation in recent years. Vietnamese law requires that $18 \%$ of final candidates for the National Assembly be from ethnic minority groups in an attempt to provide equal representation, with the most recent elections for the National Assembly resulting in 86 out of 498 seats and two ministerial cabinet positions awarded to ethnic minorities. ${ }^{46}$

\section{Gender \& Sexual Minorities}

Vietnam has made significant strides in achieving gender equality on many levels, much of which has been strengthened by the passage of the 2006 Law on Gender Equality and the 2007 Law on the Prevention and Control of Domestic Violence. ${ }^{47}$ Nevertheless, Vietnamese women continue to face serious obstacles, including poverty, limited access to higher education, fewer employment opportunities, and discriminatory societal attitudes. Despite equal legal standing on the basis of work, wages, property rights, inheritance, marriage, and divorce, subtle discriminatory provisions exist within national laws that have historically restricted opportunities for women - unequal retirement age for men (60 years) and women (55 years), for example. ${ }^{48}$ Furthermore, despite boasting one of the world's highest labor force participation rates of women over 15 years old $(72.6 \%)$, Vietnamese women were still earning less than their male counterparts across sectors. ${ }^{49}$ Within national politics, the Communist Party maintains a target of at least $30 \%$ female representation in the National Assembly, ${ }^{50}$ though that could be argued as a means of

\footnotetext{
${ }^{45}$ Ibid.

${ }^{46}$ Human Rights Watch. “The Crackdown on Labor Rights Activists.” May 4, 2009. Accessed October 30, 2018. https://www.hrw.org/report/2009/05/04/not-yet-workers-paradise/vietnams-suppression-independent-workers-movement

47 "Cross-cutting Themes: Gender." The United Nations in Viet Nam. Accessed October 31, 2018. http://www.un.org.vn/en/component/content/article.html?Itemid=\&id=1081:cross-cutting-themes-gender.

${ }^{48}$ USAID. "Country Development Cooperation Strategy for Vietnam (2014-2019).” November 8, 2013. Accessed October 7, 2018. https://www.usaid.gov/vietnam/cdes

49 "Cross-cutting Themes: Gender." The United Nations in Viet Nam. Accessed October 31, 2018.

${ }^{50}$ Ibid. http://www.un.org.vn/en/component/content/article.html?Itemid=\&id=1081:cross-cutting-themes-gender.
} 
institutionalizing gender inequities in the hope of maintaining 70\% of seats for men. ${ }^{51}$ The 2016 election failed to reach that threshold, with women only accounting for $24 \%$ of the total legislative body.$^{52}$ In the same election, however, Vietnam elected its first female Chairperson of the National Assembly, Nguyễn Thị Kim Ngân. As the first woman to enter the four pillars of Vietnam's national leadership, Nguyễn Thị Kim Ngân's election by her legislative peers has led many top voices in the country to declare significant progress for advancing gender equality. ${ }^{53}$

While the LGBTQ+ community in Vietnam still faces significant inequalities and societal discrimination, the country has been lauded by many as a trailblazer on the Asian continent for LGBTQ+ tolerance and acceptance. Although no legal protections against discrimination, Vietnam has banned conversion therapy, hosts an annual Pride parade, allows LGBTQ+ individuals to serve openly in the military, permits citizens to change their gender after sex reassignment surgery, and abolished a ban on same-sex marriage in $2015 .{ }^{54}$ Nevertheless, LGBTQ+ and gender nonconforming individuals face persistent societal discrimination and stigma that prevents many of these individuals from living openly.

\section{Competition \& Political Accountability}

Vietnam is one of the few remaining countries in the world where the Communist Party is dominant and a socialist regime is clearly established. As such, power, political ideology, and policymaking are all centralized within the Communist Party of Vietnam (CPV), which is led by

\footnotetext{
${ }^{51}$ USAID. "Democracy, Human Rights, and Governance Strategic Assessment Framework." September 2014. Accessed September 29, 2018. https://www.usaid.gov/sites/default/files/documents/1866/Master_SAF_FINAL\%20Fully\%20Edited\%209-28-15.pdf 
the Politburo and Executive Secretariat. ${ }^{55}$ This leaves little room for diverse political opinions or voices that do not align with the interests of the party. The Vietnamese government consequently limits or eliminates important aspects of competition and political accountability, including a free media, access to information, and free and fair elections.

Free Media \& Access to Information

A 2016 Freedom House Freedom of the Press report indicated that Vietnam's media environment is "one of the harshest in Asia." 56 The CPV has full legal authority and sets all guidelines for print, broadcast, online, and electronic media via the Ministry of Information and Communications and Propaganda and Education Commission. ${ }^{57}$ Despite a constitution that recognizes freedom of expression, journalists and bloggers are constrained by government authorities who often bring charges under Article 88 of the criminal code, which prohibits the dissemination of "antigovernment propaganda", and Article 79, a comprehensive ban on activities aimed at "overthrowing the state". ${ }^{58}$ Based on the 1999 Law on Media, the press is prevented from reporting information that is "untruthful, distorted, or slanderous and harmful" to an individual or organization, most notably referring to the $\mathrm{CPV}$ and state. ${ }^{59}$ Critical journalists and bloggers are actively silenced or met with arrest and conviction, with police often using violence, intimidation, and home/office raids to target those disseminating ideas believed to be harmful to national interests. ${ }^{60}$ As such, Vietnamese media is seen as a tool for the CPV to unequivocally promote messages on the party and state policy, leaving little room for alternative ideas or perspectives.

\footnotetext{
${ }^{55}$ Odell, Andrew L., and Marlene F. Castillo. "Vietnam in a Nutshell: An Historical, Political and Commercial Overview." NYSBA International Law Practicum 21, no. 2 (2008). Accessed October 14, 2018. https://www.duanemorris.com/articles/static/odell_inpr_aut08.pdf. 56 "Vietnam." Freedom House. December 01, 2016. Accessed October 20, 2018. https://freedomhouse.org/report/freedom-press/2016/vietnam.

${ }^{57}$ Vietnam 2016 Human Rights Report." U.S. Department of State, Bureau for Democracy, Human Rights and Labor. 2016. Accessed October 28, 2018. https://www.state.gov/j/drl/rls/hrrpt/2016humanrightsreport/index.htm?year=2016\&dlid=265386\#wrapper'.

58 "Vietnam." Freedom House. December 01, 2016. Accessed October 20, 2018. https://freedomhouse.org/report/freedom-press/2016/vietnam.

${ }^{59}$ Ibid.

60 "Vietnam." Freedom House. May 04, 2018. Accessed October 22, 2018. https://freedomhouse.org/report/freedom-world/2018/vietnam
} 


\section{Political Participation \& Elections}

In May 2016, Vietnamese citizens took to the polls to select members of the National Assembly in a mirage of democracy with little room for political competition. The CPV won $96 \%$ of National Assembly seats, with all candidates on the ballots either CPV candidates or non-CPV candidates who were vetted and approved by the CPV. ${ }^{61}$ While Vietnamese law does allow citizens to "selfnominate" as National Assembly candidates, academics, legal reformers, activists, and human rights defenders who registered for candidacy in 2016 never made it to the final ballot. ${ }^{62}$ Despite government claims that $99 \%$ of eligible Vietnamese citizens voted in 2016 , numerous reports have surfaced throughout the country that election officials were seen stuffing ballot boxes to ensure such an artificially high voter turnout. ${ }^{63}$ Unfortunately, state law prevents NGOs from monitoring the election process.

\section{Rule of Law \& Human Rights}

At the core of democratic governance is the rule of law and respect for human rights. As a singleparty state with highly centralized processes and institutions, Vietnam's governance is grounded in the centralization of power, corrupt public institutions, and the complete disregard for a fair and equitable judicial system.

\section{Corruption \& Transparency}

Ranked $107^{\text {th }}$ out of 180 countries in Transparency International's 2017 Corruption Index, the Vietnamese government has openly admitted that low- and high-level corruption runs rampant

\footnotetext{
${ }^{61}$ Vietnam 2016 Human Rights Report." U.S. Department of State, Bureau for Democracy, Human Rights and Labor. 2016. Accessed October 28, 2018. https://www.state.gov/j/drl/rls/hrrpt/2016humanrightsreport/index.htm?year=2016\&dlid=265386\#wrapper'.

${ }^{62}$ Ibid.

${ }^{63}$ Ibid.
} 
throughout the country. ${ }^{64}$ Issues of transparency and corruption affect every level of society and public institution, from a traffic cop accepting bribes to school principals enrolling students based on "gifts" from parents. ${ }^{65}$ Most common cases of corruption have been cited in: land administration, tax administration, customs administration, public procurement, natural resources, legislation, and within existing nongovernmental organizations. ${ }^{66}$ In Vietnam's own Provincial Competitive Index, close to $50 \%$ of foreign companies cited corruption as their biggest challenge in doing business in Vietnam. ${ }^{67}$ While the law provides criminal penalties for public officials engaged in illicit behavior, officials have continued to engage in such behaviors with impunity.

That being said, the Vietnamese government has made tackling corruption a top priority of the state and CPV in recent years. In 2013, an anticorruption law was passed that allowed citizens to voice complaints and concerns around inefficient government, poor administrative procedures, and broad instances of corruption, which was seen as an enormous victory in a state that typically restricted any criticism of public institutions. ${ }^{68}$ Under General Secretary Nguyễn Phú Trọng, anticorruption efforts have swept over Vietnam since 2016, with more than 100 high level officials currently under threat of persecution. ${ }^{69}$ In a crackdown many argue resembles China's recent efforts, the concerted effort to tackle large-scale corruption has targeted government and finance officials who have gained massive personal wealth and damaged the party image across the country. However, it could be argued that this has allowed the party to strengthen its grip on a nation reeling from rapid development.

\footnotetext{
${ }^{64}$ Transparency International. "Corruption Perceptions Index 2017." www.transparency.org. Accessed October 28, 2018. https://www.transparency.org/news/feature/corruption perceptions index 2017.

65 "Vietnam's Corruption Crackdown Is Targeting the Powerful. Has It Gone Too Far?" Los Angeles Times. January 16, 2018. Accessed October 19, 2018. http://www.latimes.com/world/asia/la-fg-vietnam-corruption-2018-2018-story.html

${ }^{66}$ Business Anti-Corruption Portal https://www.business-anti-corruption.com/country-profiles/vietnam/

${ }^{67}$ Vietnam 2016 Human Rights Report." U.S. Department of State, Bureau for Democracy, Human Rights and Labor. 2016. Accessed October 28, 2018. https://www.state.gov/j/drl/rls/hrrpt/2016humanrightsreport/index.htm?year=2016\&dlid=265386\#wrapper".

${ }^{68}$ Ibid.

69 "What's behind Vietnam's Corruption Crackdown?" Reuters. December 11, 2017. Accessed October 28, 2018. https://www.reuters.com/article/us-vietnam-security-crackdown-explainer/whats-behind-vietnams-corruption-crackdownidUSKBN1E51AO.
} 


\section{Judicial Procedures \& Criminal Justice System}

The Vietnamese judicial system is comprised of several levels of courts, tribunals, and a Supreme People's Procuracy, with a court hierarchy of Supreme People's Court, Provincial Courts, and District Courts. ${ }^{70}$ Article 31 of the Vietnamese Constitution outlines the judicial system's role and power, noting that all persons are equal before the law, that defendants are innocent until proven guilty, and that they have the right to a defense lawyer and speedy public trial. ${ }^{71}$ Yet in practice, much of these constitutional guarantees are not upheld. Defense lawyers have complained that judges make determinations of guilt before conducting a trial, and sensitive cases have been found to be closed to the public despite constitutional guarantees otherwise. ${ }^{72}$ Political influence and widespread inefficiencies have been quoted in stifling the effectiveness of the judicial system, with most judges beholden to senior government officials and the wishes of the CPV. ${ }^{73}$ In fact, all judges are members of the CPV and must undergo vetting by the party in order to determine their suitability for the bench, suggesting that the true authoritative power of the courts lies in the concentrated hands of the CPV. ${ }^{74}$

Additionally, a 2018 Human Rights Watch report found that trials of activists consistently failed to meet international fair standards. ${ }^{75}$ Police brutality and intimidation were found to be extensively common, with multiple deaths of individuals arrested for crimes against the state while in police custody. Government detention centers that use forced labor as a means of punishment are common, with most detained due to drug use. ${ }^{76}$ Detainees have described inhumane treatment

\footnotetext{
${ }^{70}$ Odell, Andrew L., and Marlene F. Castillo. "Vietnam in a Nutshell: An Historical, Political and Commercial Overview." NYSBA International Law Practicum 21, no. 2 (2008). Accessed October 14, 2018. https://www.duanemorris.com/articles/static/odell_inpr_aut08.pdf.

${ }^{72}$ Vietnam 2016 Human Rights Report." U.S. Department of State, Bureau for Democracy, Human Rights and Labor. 2016. Accessed October 28, 2018. https://www.state.gov/j/drl/rls/hrrpt/2016humanrightsreport/index.htm?year=2016\&dlid=265386\#wrapper'. 
and severe mental and physical abuse in these centers, often including the deprivation of food and water should work quotas not be met. ${ }^{77}$ In the first six months of 2017 , state media announced that it had sent 3,168 people to detention centers in Ho Chi Minh City due to drug use. ${ }^{78}$

\section{Government Responsiveness and Effectiveness}

Disparities between populations exist in Vietnam as a result of rapid economic development and a one-party political system. Historically, the Vietnamese government has been slow to respond to issues affecting the public, particularly following the Vietnamese-American War and immediately following the Đổi Mới reforms. However, in the past two decades, the country has made immense progress in responding to public needs and interests. That said, widespread corruption of public institutions and the inability for citizens to vocalize discontent with state systems remain significant obstacles in Vietnam's pursuit of government responsiveness and effectiveness.

\section{Health \& Human Development}

Development efforts within Vietnam's health services sector over the past decade have improved human welfare and responded to the growing health needs of the public. Nevertheless, Vietnam's healthcare system remains significantly underdeveloped with inequitable resource distribution among citizens, particularly those living with HIV/AIDS and within the disabled community. Vietnam has a concentrated HIV/AIDS epidemic among injecting drug users (IDUs), men who have sex with men (MSM), and sex workers. Although Vietnam has what USAID claims to be a good legal and policy environment for a national HIV/AIDS response, considerable policy barriers

\footnotetext{
77 “Vietnam's Forced Labor Centers." International Labor Rights Forum. January 14, 2014. Accessed October 28. 2018. https://laborrights.org/publications/vietnams-forced-labor-centers

78 "World Report 2018: Rights Trends in Vietnam." Human Rights Watch. January 18, 2018. Accessed October 28, 2018. https://www.hrw.org/world-report/2018/country-chapters/vietnam.
} 
and institutional management issues have made delivering a comprehensive range of government services incredibly difficult. ${ }^{79}$ Similarly, although Vietnam has made progress in developing policy for its 13.5 million disabled citizens, existing disability policies are not adequately enforced at the national level and virtually nonexistent at the local. ${ }^{80}$ Although citizens and international NGOs continue to call for increased funding and accountability on behalf of this community and others within the health sector, the Vietnamese government has yet to allocate enough resources and leadership to this growing public need. ${ }^{81}$

\section{Fiscal Legitimacy \& Tax Policy}

Over the past 20 years, fiscal policy and management has allowed the Vietnamese government to prioritize government spending on public services, particularly among the most disadvantaged. ${ }^{82}$ However, new challenges and fiscal pressures currently exist as a result of rapid economic growth, including increased demand for citizen fiscal information, larger investments requiring mediumterm planning, and increased decentralization of public service delivery. ${ }^{83}$ In a 2016 World Bank report, experts called for reforms of the state's fiscal policies and management to ensure the rapid economic growth could meet public service demand, particularly as it relates to efficiency of spending and fiscal transparency. ${ }^{84}$ Notwithstanding these calls for reform and the widespread corruption apparent throughout Vietnam's bureaucracy and public institutions, a recent OECD report claims that overall trust in authorities regarding budgetary issues is high among citizens. ${ }^{85}$

\footnotetext{
${ }^{79}$ USAID. "Democracy, Human Rights, and Governance Strategic Assessment Framework." September 2014. Accessed September $29,2018$. https:/www.usaid.gov/sites/default/files/documents/1866/Master_SAF_FINAL\%20Fully\%20Edited\%209-28-15.pdf

${ }^{80}$ Ibid.

${ }^{81}$ Ibid.

82 "Fiscal Management Reform for Middle-Income Vietnam." World Bank. Accessed October 29, 2018.

${ }^{83}$ Ibid. http://www.worldbank.org/en/results/2016/04/15/fiscal-management-reform-for-middle-income-vietnam.

${ }^{84}$ Ibid.

${ }^{85}$ OECD. "Social Cohesion Policy Review of Viet Nam.” Development Centre Studies, OECD Publishing, October 28, 2014. Accessed October 27, 2018. Paris, https://doi.org/10.1787/9789264196155-en.
} 
This level of confidence is likely due in part to the party's 2011 decision to allow civic participation in fiscal policymaking, which has led to $74 \%$ of surveyed citizens believing the accuracy and legitimacy of state budget information ${ }^{86}$ Similarly, Vietnamese citizens overwhelmingly believe that tax evasion is never justifiable, despite only $35 \%$ of workers' wages being in registered enterprises being reported to Vietnam Social Security (VSS). ${ }^{87}$

\section{Climate Change \& Environmental Rights}

From a global perspective, Vietnam is among the five most vulnerable countries to climate change given its lengthy coast and low-lying deltas ${ }^{88}$ Although the government has committed itself on paper to tackling environmental issues in the interest of public health and safety, little has been done to turn this commitment into action. In April 2016, protests rocked the central coastal region as a toxic chemical spill from the Taiwan-owned Formosa Plastics Group's factory left fisherman out of a livelihood and an entire ecosystem distraught.$^{89}$ The government's response was muted, instead focusing on the value of the company's investment in the economically disadvantaged region and less on the environmental and economic damage the spill would continue to wreak for years to come. Although locals protested with calls for the government to respond to this environmental disaster with policies and programs that would protect their community from further damage, the provincial and national governments turned a blind eye. Unfortunately, no formal mechanisms existed to allow concerned citizens the opportunity to hold their government accountable.

\footnotetext{
${ }^{86} \mathrm{Ibid}$.

${ }^{87}$ Ibid.

${ }^{88}$ USAID. "Democracy, Human Rights, and Governance Strategic Assessment Framework." September 2014. Accessed September $29,2018$. https://www.usaid.gov/sites/default/files/documents/1866/Master SAF FINAL\%20Fully\%20Edited\%209-28-15.pdf

89 "Fishermen Again Protest in Central Vietnam Over 2016 Toxic Spill Payout." Radio Free Asia. January 24, 2018. Accessed October 28, 2018. https://www.rfa.org/english/news/vietnam/formosa-protests-01242018163710.html.
} 
It should be noted here that the USAID framework does not adequately capture the importance of climate change policies and environmental rights in promoting and fostering democracy, human rights, and good governance. In particular, environmental protection policies greatly affect the poor, as these economically marginalized communities tend to be more reliant on environmental goods and services for their livelihoods and incomes. ${ }^{90}$ Moreover, recent studies have concluded that climate change can influence political factors that create or exacerbate conflict within states, most notably due to natural resource scarcity and pollution-related health risks. ${ }^{91}$ As such, it is recommended that the USAID framework look to including climate change, environmental rights, and biodiversity protection questions when assessing a government's responsiveness and effectiveness to public needs and interests.

\section{PROBLEM IDENTIFICATION}

One of Vietnam's most critical threats to democratic transition and long-term political development lies in the evolution of the state's labor rights regime to meet international labor standards. Vietnam's existing labor rights regime currently lies at the tense intersection of maintaining political stability and promoting economic development, and has long disregarded fundamental international labor standards, including the freedom of association and collective bargaining, abolition of forced labor as a means of legal punishment, elimination of child labor, and the freedom from discrimination. The lack of effective labor laws and policies prevents the government from serving the interests of all citizens, while also stymieing political and economic development. The Vietnamese government must actively reform its labor rights regime and

\footnotetext{
${ }^{90}$ Irish Aid. "Environment and Governance." 2017. Accessed October 30, 2018. https://www.irishaid.ie/media/irishaid/allwebsitemedia/20newsandpublications/publicationpdfsenglish/

${ }^{91}$ Sida. "The relationship between climate change and violent conflict." 2017. Accessed October 30, 2018. https://www.sida.se/contentassets/c571800e01e448ac9dce2d097ba125a1/working-paper---climate-change-and-conflict.pdf
} 
institute rule of law and respect for human rights in order to ensure all citizens are respected and their ability to participate in the political and economic process is upheld.

\section{ANALYTICAL CONCLUSION: LABOR RIGHTS IN VIETNAM}

\section{What are Labor Rights?}

Work is a vital human institution, particularly for the means of aggregating societal wealth. At the core of human productivity and development lies the essence of labor rights. Yet lawyers, academics, and activists alike have long doubted the inclusion of labor rights within human rights discourse. For many of the skeptics, the foundation for which labor rights exists - the idea that they are only designated to those with a particular status of employment - signifies that they are not, like human rights, granted to every human being. Moreover, these skeptics have further claimed that human rights pertain to the relationship between the state and the individual, particularly as it relates to the limitation of the power of the state, whereas labor rights are based within the relationship shared between private actors and workers as it relates to the limitation of the power of the employer. ${ }^{92}$

In an attempt to achieve moral, political, and legal consensus on what constitutes universally recognized labor rights, the International Labor Organization (ILO) created the Fundamental Declaration on Principles and Rights at Work in $1998 .{ }^{93}$ Within the Declaration, the ILO designated four categories of core labor rights: 1) freedom of association and collective bargaining; 2) abolition of forced labor; 3) elimination of child labor; and 4) freedom from

\footnotetext{
${ }^{92}$ Kolben, Kevin. “Labor Rights as Human Rights?” Virginia Journal of International Law 50:2: 449-484. 2010.

${ }^{93}$ ILO. "ILO Declaration on Fundamental Principles and Rights at Work". June 1988. Accessed October 30, 2018. http://www.ilo.org/declaration/lang--en/index.html
} 
discrimination.${ }^{94}$ For the purposes of this analysis, the protection and promotion of labor rights will be considered the sine qua non of human rights.

\section{Labor Rights \& Rule of Law}

USAID identifies rule of law as one of the five key elements of democracy, human rights, and governance, and thus a key component of a country's political development. Although the definition of rule of law is contested and opaque, for the sake of this analysis the USAID definition will be employed: "rule of law is a principle of governance in which citizens, corporations, and the state itself obey the law, and the law itself is derived from a democratic consensus." ${ }^{95}$ Underscored in this definition is the principle that all members and institutions of a society are accountable to the law and adhere to international norms of human rights. USAID furthers their definition of rule of law to claim that in order for rule of law to predominate over social organizations and actors, the following five elements must also be present: order and security, legitimacy, checks and balances, fairness, and effective application. ${ }^{96}$

With this contextualization in mind, we can turn to each of the manifestations of labor rights detailed above - freedom of association and collective bargaining, abolition of forced labor, elimination of child labor, and freedom from discrimination - to recognize the crucial role labor rights play in promoting a state's political development.

\footnotetext{
${ }^{94}$ Ibid.

${ }^{95}$ USAID. "Democracy, Human Rights, and Governance Strategic Assessment Framework." September 2014. Accessed September $29,2018$.

${ }^{96}$ Ibid. https://www.usaid.gov/sites/default/files/documents/1866/Master SAF FINAL\%20Fully\%20Edited\%209-28-15.pdf
} 


\section{Current Status of Labor Rights in Vietnam}

In December 2017, the Vietnamese government reaffirmed its commitment to the 1998 Fundamental Declaration on Principles and Rights at Work. ${ }^{97}$ Despite this reaffirmation, Vietnam has only ratified five out of the eight ILO fundamental Conventions, not including No. 87 on Freedom of Association and Protection of the Right to Organise, No. 98 on the Right to Organise and Collective Bargaining, and No. 105 on the Abolition of Forced Labour. ${ }^{98}$ In recent displays of commitment to the European Union, the Vietnamese government has signaled that the period of 2017-2021 will be marked by critical reform of labor market institutions, including joining these Conventions and concrete action on reforming existing policies and practices. Despite this commitment, the Vietnamese Ministry of Labor, Invalids, and Social Affairs (MoLISA) has only marginally attempted to implement and enforce labor laws that align with international standards.

Additionally, in response to Vietnam's rapid economic growth in recent years, the government and private sector have relied on Vietnam's hard-working and low-paid workforce including children - as a selling point to attract foreign investors at the cost of worker safety, dignity, and fundamental rights. ${ }^{99}$ Moreover, Vietnam's longstanding use of "labor therapy" better referred to as forced labor - as a means of criminal and corrective punishment is in stark violation of international labor standards. ${ }^{100}$

\footnotetext{
${ }^{97}$ ILO. “Decent Work Country Programme: 2017-2021.” December 5, 2017. Accessed October 30, 2018. https://www.ilo.org/wcmsp5/groups/public/---asia/---ro-bangkok/---ilo-hanoi/documents/publication/wcms 630293.pdf https://www.everycrsreport.com/reports/RL30896.html.

${ }^{100}$ International Labor Rights Forum. "Vietnam’s Forced Labor Centers.” January 2014. Accessed October 24, 2018. https://laborrights.org/our-work/forced-labor-vietnam
} 


\section{Freedom of Association and Right to Collective Bargaining}

The freedom of association and the right to collective bargaining translate into an individual's ability to form or join a trade union and the right to engage in free conversation with employers regarding work conditions. Both freedom of association and the act of collective of bargaining are deeply rooted and engrained within the functions of democracy and sustained political development, allowing for active democratic representation and accountability. ${ }^{101}$ Unfortunately, Vietnam actively prevents and suppresses any citizen activity related to either of these foundational labor rights.

In Vietnam, a monopoly on the trade union system is legally imposed and actively enforced across the country. Existing labor laws prohibit any worker from forming or joining a trade union of their choice, instead requiring that all unions be approved and affiliated with the Vietnam General Confederation of Labor (VGCL), a self-described "member of the political system under the leadership of the Communist Party of Vietnam." 102 The Vietnamese government has actively targeted, prosecuted, and imprisoned citizens who have attempted to form independent trade unions within the past decade. ${ }^{103}$ Examples of this enforcement include: Trần Khải Thanh Thủy, a writer who founded the Công Đoàn Độc Lập Việt Nam (Vietnam Independent Trade Union), convicted of "disturbing the peace" and sentenced to 3.5 years in prison; and Nguyễn Tấn Hoành, a factory worker who founded the Hiệp Hội Đoàn Kết Công-Nông Việt Nam (United Workers and Farmers Association of Vietnam), who was imprisoned for 18 months on charges of "spreading propaganda" to oppose the state. ${ }^{104}$ Despite a government decision to relax labor laws and allow

\footnotetext{
${ }^{101}$ Rodgers, Gerry, Eddy Lee, Lee Swepston, Jasmien Van Daele. 2009. The International Labour Organization and the quest for social justice, 1919-2009. Ithaca: Cornell University Press.

${ }^{102}$ VGCL, Statutes of the Vietnamese Trade Unions (Nov. 5, 2008), http://www.congdoanvn.org.vn/english/details

${ }^{103}$ Worker Rights Consortium. "Made in Vietnam: Labor Rights Violations in Vietnam’s Export Manufacturing Sector.” May 2013. Accessed

104 Ibid. October 30, 2018. http://www.workersrights.org/linkeddocs/WRC Vietnam Briefing Paper.pdf
} 
unions between 2005-2006, the government quickly reversed this decision and instead ramped up campaigns for the persecution and imprisonment of individuals engaged in labor activism. ${ }^{105}$

The denial of associational rights to Vietnamese workers is only worsened with the state's zero tolerance for worker strikes and protests, as well as active suppression of a worker's ability to voice concerns related to working conditions. Although the right to strike is protected under international labor rights and considered a necessary element of collective bargaining, strike and protest organizers in Vietnam face dismissal and blacklisting by employers and prosecution and imprisonment by state authorities. ${ }^{106}$ In 2006, strikes at foreign-owned factories shook Ho Chi Minh City and surrounding southern provinces, with more than 350,000 workers demanding wage increases and better working conditions. The Vietnamese government immediately deemed these strikes illegal, responding with large numbers of government authorities who used force to disperse and arrest any participants. ${ }^{107}$

During Trans-Pacific Partnership (TPP) negotiations with the United States, the Vietnamese government made a surprising commitment to allow independent labor unions and collective bargaining within the country in order to meet the Obama administration's demands. This sweeping revision of the Labor Code was put on the agenda for the National Assembly in 2016, signaling a full commitment to bring elements of association and collective bargaining to all Vietnamese workers. ${ }^{108}$ Unfortunately, with the Trump administration's decision to pull out of the TPP, any hope of labor reform on these fronts disappeared with the Vietnamese government no

\footnotetext{
105 Ibid.

${ }^{106}$ Worker Rights Consortium. “Made in Vietnam: Labor Rights Violations in Vietnam's Export Manufacturing Sector.” May 2013. Accessed October 30, 2018. http://www.workersrights.org/linkeddocs/WRC Vietnam Briefing Paper.pdf

107 "Not Yet a Workers' Paradise | Vietnam's Suppression of the Independent Workers' Movement." Human Rights Watch. April 29, 2015. Accessed October 30, 2018. https://www.hrw.org/report/2009/05/04/not-yet-workers-paradise/vietnams-suppression-independentworkers-movement.

${ }^{108}$ Pham, Nghia Trong. "Will TPP's Death Kill Labor Rights Reform in Vietnam?" The Diplomat. July 14, 2017. Accessed October $31,2018$. https://thediplomat.com/2017/07/will-tpps-death-kill-labor-rights-reform-in-vietnam/.
} 
longer seeing the benefit of such reform without U.S. involvement in the trade deal. ${ }^{109}$ This reversal on behalf of the Vietnamese government calls into question the extent to which the original commitment to labor reform would have truly been upheld and supported.

\section{Abolition of Forced Labor}

Forced or compulsory labor is defined by ILO Convention No. 29 as "all work or service, which is exacted from any person under the menace of any penalty and for which the said person has not offered himself voluntarily." 110 A citizen's ability to be free of violence and intimidation - as well as guaranteed due process and fair and humane punishment - are all foundational to the functions of democracy and sustained political development. However, Vietnam's use of forced labor as a punitive measure against its own citizens, especially those accused of illegal drug usage, only prevents political development and democratization.

In 1995, the Vietnamese National Assembly stated that drug addicts “...shall be sent to health institutions for treatment, education, and manual labor for three months to one year."111 These state-run "rehabilitation centers" are reportedly run in a military "boot camp" style, including early morning wake up calls, mandatory exercises, state-sponsored indoctrination, and "labor therapy."112 According to a 2013 Human Rights Watch report, 120 detention centers were operational throughout Vietnam with a total of 40,000 detainees, some of whom were just twelve years old. ${ }^{113}$ Within these centers, reported examples of forced labor have included: cashew nut

\footnotetext{
${ }^{109}$ Ibid.

${ }^{110}$ ILO. "Forced Labor Convention 29." Accessed November 1, 2018. http://www.refworld.org/docid/3ddb621f2a.html

${ }^{111}$ International Labor Rights Forum. "Vietnam's Forced Labor Centers.” January 2014. Accessed October 24, 2018. https://laborrights.org/our-work/forced-labor-vietnam

${ }^{112}$ Worker Rights Consortium. "Made in Vietnam: Labor Rights Violations in Vietnam's Export Manufacturing Sector." May 2013. Accessed October 30, 2018. http://www.workersrights.org/linkeddocs/WRC Vietnam Briefing Paper.pdf

${ }^{113}$ Human Rights Watch, World Report 2013: Vietnam, http://www.hrw.org/world-report/2013/country-chapters/vietnam?page=3.
} 
processing, sewing and embroidery, painting ceramic trinkets, and carving stone jewelry. ${ }^{114}$ Workers are subject to daily production quotas, which if not met, can leave detainees liable to physical punishment, food deprivation, and solitary confinement. ${ }^{115}$ Instances of staff beating detainees with wooden clubs and electrical batons have been reported, as well as one instance of a woman hung from her hands for one week when caught trying to escape. ${ }^{116}$ A 2011 Human Rights Watch report portrayed Que Phong, a man from Ho Chi Minh City, who was detained in a rehabilitation center for five years due to heroin usage. His account details long days of cashew nut husking with guards slapping and punching detainees who stopped to take even the smallest of breaks. Although given a 12-month sentence upon arrival, Que Phong was detained for more than five years and subject to repeated abuse, humiliation, and intense manual labor. ${ }^{117}$

Forced labor is also apparent in Vietnam's apparel industry, with major companies like Columbia Sportswear, Singapore's Ocean Sky Group, and Nike all accused at some point in the past decade of contracting with work centers who relied on forced or slave labor to meet production quotas. ${ }^{118}$ In October 2012, workers at Hong Fu Vietnam Footwear Company - a supplier of Nike's Converse subsidiary brand at the time - reported a Chinese supervisor supergluing Vietnamese workers' hands when production quotas were not met or the quality of work did not meet expectations. ${ }^{119}$ Instances of forced labor within the private sector - including sex trafficking, servitude, and forced prostitution - continue to plague Vietnamese society despite recent governmental efforts.

\footnotetext{
${ }^{114}$ International Labor Rights Forum. "Vietnam’s Forced Labor Centers.” January 2014. Accessed October 24, 2018.

https://laborrights.org/our-work/forced-labor-vietnam

${ }^{115}$ Ibid.

${ }^{116}$ The Rehab Archipelago | Forced Labor and Other Abuses in Drug Detention Centers in Southern Vietnam." Human Rights Watch. January 29, 2016. Accessed October 31, 2018. https://www.hrw.org/report/2011/09/07/rehab-archipelago/forced-labor-and-other-abuses-drug${ }^{117}$ Ibid. detention-centers-southern.

${ }^{118}$ Worker Rights Consortium. "Made in Vietnam: Labor Rights Violations in Vietnam's Export Manufacturing Sector.” May 2013. Accessed ${ }^{119}$ Ibid. October 30, 2018. http://www.workersrights.org/linkeddocs/WRC Vietnam Briefing Paper.pdf
} 


\section{Elimination of Child Labor}

Child labor can be defined as the "work performed by children who are under the minimum age legally specific for that kind of work, or work which, because of its detrimental nature or conditions, is considered unacceptable for children." ${ }^{120}$ Like forced labor, the abolition of child labor is crucial for a state's sustained political development and democratization, in that it provides a sense of personal security and fairness that is crucial to maintaining rule of law.

According to 2015 estimates, almost $10 \%$ of the Vietnamese youth population under 18 years old was considered a laborer. ${ }^{121}$ Child labor within Vietnam most often relates to instances of crowded factories and agricultural farms, both with expectations of long hours and often with little to no pay. In particular, Vietnam's apparel and garment industries are considered by international organizations and the U.S. Department of Labor as primary culprits in the country's child labor regime. ${ }^{122}$ Due to a lack of reliable means for verifying the ages of new employees, a 2013 ILO report found that $72 \%$ of factories in Vietnam were unaware if they were employing underage workers. ${ }^{123}$ That being said, a 2012 U.S. Department of State report found child laborers present in 110 factories in and around the Ho Chi Minh metropolitan area, with most working more than twelve hours days. ${ }^{124}$

Particularly commonplace in Vietnam is the trafficking of children from rural villages to factories in metropolitan areas and even abroad in order to send remittances back to their families. In some cases, garment factory owners have been reported travelling to rural districts for child

\footnotetext{
${ }^{120}$ International Labor Conference. 2012. "101" Session Report: Giving globalization a human face." General Survey on the fundamental Conventions concerning the rights at work in light of the ILO's Declaration on Social Justice for a Fair Globalization. Geneva. 
workers, offering \$50-\$100 USD to parents in exchange for their child's manpower. ${ }^{125}$ A 2013

$\mathrm{BBC}$ report detailed the story of a Vietnamese boy who had just turned 18 years old and was taken

from his rural village to work at a factory where youth workers were placed in a small room and

forced to work 18 hour days with little compensation. ${ }^{126}$ In this same example, child laborers were given drugs to stay alert and awake for longer periods of time. ${ }^{127}$

\section{Freedom from Discrimination}

Although freedom from discrimination in the workplace has most commonly referred to gender, race, and ethnicity, recent trends in international labor standards have moved to expand these "statuses" to include HIV status, sexual orientation, age, employment status, education level, and ability. ${ }^{128}$ As stated in the USAID framework, for a country to embody democratic principles, "formal rules and informal practices must be inclusive of all segments of the population." 129 All citizens within a state must have free access and the ability to participate in economic and social life. Discrimination on the basis of any of the identities mentioned above, particularly in relation to employment and labor practices, is undemocratic and in opposition to political development.

In what many labor rights activists see as progress, recent amendments to Vietnam's labor law mandates relatively generous maternity benefits to female workers, including six months of paid leave. ${ }^{130}$ Unfortunately, in practice, employers are repeatedly found to engage in

\footnotetext{
${ }^{125}$ Worker Rights Consortium. “Made in Vietnam: Labor Rights Violations in Vietnam's Export Manufacturing Sector.” May 2013. Accessed October 30, 2018. http://www.workersrights.org/linkeddocs/WRC_Vietnam_Briefing_Paper.pdf

${ }^{126}$ Brown, Marianne. "Vietnam's Lost Children in Labyrinth of Slave Labour." BBC News. August 27, 2013. Accessed October $31,2018$. https://www.bbc.com/news/world-asia-23631923.

${ }^{127}$ Worker Rights Consortium. "Made in Vietnam: Labor Rights Violations in Vietnam's Export Manufacturing Sector.” May 2013. Accessed October 30, 2018. http://www.workersrights.org/linkeddocs/WRC Vietnam Briefing Paper.pdf

${ }^{128}$ International Labor Conference. 2012. "101" Session Report: Giving globalization a human face.” General Survey on the fundamental Conventions concerning the rights at work in light of the ILO's Declaration on Social Justice for a Fair Globalization. Geneva.

${ }^{129}$ USAID. "Democracy, Human Rights, and Governance Strategic Assessment Framework.” September 2014. Accessed September $29,2018$. https://www.usaid.gov/sites/default/files/documents/1866/Master SAF FINAL\%20Fully\%20Edited\%209-28-15.pdf

${ }^{130}$ Worker Rights Consortium. "Made in Vietnam: Labor Rights Violations in Vietnam's Export Manufacturing Sector.” May 2013. Accessed October 30, 2018. http://www.workersrights.org/linkeddocs/WRC Vietnam_Briefing_Paper.pdf
} 
discriminatory practices against female workers in an attempt to avoid these mandated benefits. Most notably, at a Korean-owned export manufacturer of cosmetic brushes, female workers were contractually required to not become pregnant for at least three years after being hired. ${ }^{131}$ When workers did have children, the company was also cited in failing to provide the workers with any legally required maternity benefits. Despite existing labor law, Vietnamese authorities failed to respond to the claims of the women workers, citing the economic importance of the Korean factory's presence in the country. ${ }^{132}$

Access to decent work enables people with disabilities to improve their living conditions, actively participate in society, and take full advantage of equal economic opportunities. Nevertheless, Vietnam's 13.5 million disabled citizens routinely experience discriminatory practices when attempting to find work. ${ }^{133}$ Although the Vietnamese Law on Disabled Persons encourages businesses to hire individuals with disabilities, little is done by authorities to enforce this law. ${ }^{134}$ As a result, negative social attitudes continue to limit most job opportunities for disabled citizens, with most opportunities strictly limited to small handcrafts and woodwork. ${ }^{135}$

\section{Origins \& Implications for Vietnam's Labor Regime: A Political Development Perspective}

Violations of basic labor rights remain pervasive throughout Vietnam, particularly in the garment and manufacturing industries. Current state policies are repressive and do little to acknowledge or address existing abuses of international labor standards. Based on the USAID analysis, it is evident that at the core of Vietnam's appalling labor regime lies two distinct root causes: 1) maintaining

\footnotetext{
${ }^{131}$ Ibid.

${ }^{132}$ Worker Rights Consortium. “Made in Vietnam: Labor Rights Violations in Vietnam’s Export Manufacturing Sector.” May 2013. Accessed October 30, 2018. http://www.workersrights.org/linkeddocs/WRC Vietnam Briefing Paper.pdf

${ }^{133}$ ILO. "Inclusion of People with Disabilities in Viet Nam.” January 2013. Accessed October 31, 2018. https://www.ilo.org/wcmsp5/groups/public/---ed emp/---ifp skills/documents/publication/wcms 112407.pdf

${ }^{134}$ USAID. “Country Development Cooperation Strategy for Vietnam (2014-2019).” November 8, 2013. Accessed October 7, 2018.

${ }^{135}$ Ibid. https://www.usaid.gov/vietnam/cdcs
} 
political stability through complete party control over civil society actors, the judicial and criminal justice system, and political organizations, with zero tolerance of dissident voices; and 2) promoting economic growth and private sector development at the expense of rule of law and human rights.

Freedom of association and collective bargaining each represent crucial components of a well-functioning democracy, most notably the ability of a representative body to legitimately interact and influence policy that directly affects the needs and interests of workers. ${ }^{136}$ Active unions have been also been cited in creating a means of arbitration for promoting fairness and legitimacy in dispute resolution, which is important and necessary in any well-functioning democratic society. ${ }^{137}$ Allowing citizen workers an active voice to express aspirations enables them to participate in the framing and implementing of economic and social policy, a key element of sustained and democratic political development. Similarly, the effective abolition of forced and child labor addresses the violence, intimidation, and human rights abuses that are perpetuated by state and non-state actors in the absence of rule of law. The use of forced labor as a means of punishment and the failure to address the use of child labor violates norms of due process and individual rights and dignity, ultimately corroding efforts of political development and democratic transition. ${ }^{138}$ Finally, discriminatory labor practices on the basis of sex, gender identity, ability, ethnicity, religion, education level, and/or other perceived identities is a threat to the rule of law's need for fairness and order and security. When certain populations are not afforded the same opportunities as their peers, a state's rule of law is delegitimized. Therefore, without adequate

\footnotetext{
${ }^{136}$ Becker, Jeff. "Organized Labor's Role in Democratic Transitions." Center for American Progress. June 20, 2011. Accessed October $31,2018$. 137 Ibid.

${ }^{138}$ USAID. "Democracy, Human Rights, and Governance Strategic Assessment Framework.” September 2014. Accessed September 29, 2018. https://www.usaid.gov/sites/default/files/documents/1866/Master_SAF FINAL\%20Fully\%20Edited\%209-28-15.pdf
} 
worker protections against discriminatory practices, a state's political and democratic development are undermined.

\section{RECOMMENDATIONS}

\section{Leveraging the Economic Power of Vietnam's Trading Partners}

- As the Vietnamese government places great emphasis on the economic and societal gain of foreign investment and international trade, Vietnam's trading partners should not provide Vietnam with greater market access until the government effectively ends forced and child labor, closes the drug detention centers, and initiates broad sweeping labor law reforms allowing independent labor unions.

- Goods produced using forced and/or child labor in Vietnam should be added to national and international lists of goods from around the world that are produced using forced or child labor, thereby discouraging trading and purchasing of said goods until labor reforms are made.

\section{Action on Behalf of International Corporations that Source Goods from Vietnam}

- Corporations relying on goods produced in Vietnam should comply with the United Nations' Guiding Principles on Business and Human Rights in order to conduct the necessary due diligence on goods to ensure they are not produced using forced or child labor.

- Corporations should issue public statements to the Vietnamese government calling for the effective abolition of forced and child labor, as well as the creation of independent labor unions and anti-discrimination policies, or risk losing key investments. 


\section{Minimum Wage for Non-State Employment}

- The National Industrial Relations Committee (NIRC) of the CPV should recommend the Prime Minister and National Assembly develop comprehensive minimum wage policies for all workers, especially non-state employees, in order to decrease the need for children to work for increased family income.

\section{Judicial \& Criminal Justice System Reform}

- The CPV should cease all vetting and approval of judges, instead permitting a free and independent judicial and criminal justice system that upholds due process and fair trials that eliminate the potential for forced labor as a form of punishment.

\section{Creating Rehabilitation Facilities for Drug Users}

- The Ministry of Labor, Invalids, and Social Affairs (MoLISA) should release all drug center detainees and permanently close all drug detention centers.

- Expand access to community-based drug treatment services that offer counseling, employment prospects, and housing assistance to individual suffering from drug addiction, especially for individuals who are only occasional or moderate drug users.

\section{Independent Labor Unions}

- The Vietnamese government should uphold its commitment to the International Labor Organization and allow for freedom of association and collective bargaining found in the formation of independent labor unions completely uninfluenced by the CPV. 
- Vietnamese law should also recognize the formation of independent labor unions and their ability to allow strikes, protests, and contestations with employers over working conditions. 